\title{
In MEMORIAM OF ELEANOR DEARMAN KINNEY - PROFESSOR OF LAW
}

\author{
WILLIAM H. THOMPSON, ESQ.
}

I am honored to submit this essay in memory of Eleanor Kinney. What better soul to celebrate than that of Professor Kinney! Professor Kinney helped educate and mentor two generations of Indiana healthcare lawyers. I had the good fortune of being one of those lawyers.

I have to start with how I first met Professor Kinney. In the early 1980s, I had just finished my Master of Science in Health Administration and accepted a position at Indiana University Hospital. Prior to that, I had worked for three years at Wishard Hospital (now Eskenazi Health) in several lower-level administrative roles. It was at Indiana University Hospital that I first contemplated going to law school. John Render, then Chair of Hall Render, had taught the Health Law class in my MHA program - John inspired me to go beyond health administration and pursue health law.

So, with the help of Dean Frandsen, I was admitted to the evening program of the Indiana University Robert H. McKinney School of Law in 1983. Upon arrival, I was disappointed as to the lack of classes that had much to do with health law. There was Law and Medicine, taught by Professor Larry Wilkins, a torts class, and not much else. Of course, at that time health law was just coming into its own as a recognized sector of the law.

Enter Professor Kinney in 1986. Wow, what a force! I was immediately impressed with Eleanor's real-world experience. She had worked at the Department of Health and Human Services and as a Deputy General Counsel at the American Hospital Association - she was a true health lawyer! I gravitated immediately to Eleanor as someone I knew could help me pursue a career in health law. Eleanor was incredibly receptive to my advances and my neverending questions and eagerness to find classes to help me become a health lawyer. Eleanor was always so gracious and genuine. She and her husband, Charlie, would invite me to receptions at their beautiful home where out-of-town health law scholars would come to discuss important issues in health law. The conversations were always enlightening. No other professor had extended such an invitation to me, but that was Eleanor - no pretense, and always a willingness to include students and to encourage them to learn.

When I finished law school in 1987, Eleanor was instrumental in helping me obtain an associate position at Hall Render-Hall Render is where I wanted to be from the very beginning. Eleanor had become a colleague and good friend of Bill Hall and John Render and pointed me in the direction of their firm, for which I am eternally grateful. As an aside, Eleanor and Bill Hall had a special relationship. They were at the opposite ends of the political spectrum, but greatly respected each other's views. They both believed that access to high quality and affordable healthcare was a basic human right. I had the opportunity to sit in on a number of discussions between Bill and Eleanor, on far-ranging topics of health policy and law, from the Clinton Health Plan and Medicare policy, to the

* Chair, Hall, Render, Killian, Heath \& Lyman, PC 
differences in the delivery systems of Latin American countries. I never failed to learn something from those discussions, much of which remains relevant in my practice today.

In 1986, Bill Hall and his wife, Christine, made a generous contribution to McKinney's Center of Law and Health. The Center was renamed as the "William S. and Christine S. Hall Center for Law and Health" in recognition of Bill and his wife's remarkable contribution. Professor Kinney was named the Center's first Director. The Hall Center flourished under Eleanor's guiding hand, and it continues to flourish today under Professor Terry's leadership.

All of us at Hall Render are incredibly proud of what the Center has accomplished, from its expansive health law curriculum, to its joint degree programs, and to its incredible research on the opioid crisis. The Health Law Program has been recognized as one of the top ten programs in the country, thanks to Eleanor's vision and the strong support of the Health Law Professors and leadership of the Indiana University McKinney School of Law.

The Center will forever rest on the spirit of Professor Kinney. She was truly one of a kind!

Rest in Peace Eleanor. 